\title{
THE BIOLOGY OF SENEGALESE GRASSHOPPER (OEDALEUS SENEGALENSIS, KRAUSS, 1877) (ORTHOPTERA: ACRIDIDAE)
}

\author{
Abdelmanan E. H. Elamin ${ }^{1}$--- Abdalla M. Abdalla ${ }^{2}$-- Ahmed M. El Naim ${ }^{3}$ \\ ${ }^{\prime}$ Department of Plant Protection Sciences, Faculty of Natural Resources and Environmental Studies, University of \\ Kordofan, Elobeid, Sudan \\ ${ }^{2}$ Department of Plant Protection Sciences, Faculty of Natural Resources and Environmental Studies, University of \\ Kordofan, Elobeid, Sudan \\ ${ }^{s}$ Department of Crop Sciences, Faculty of Natural Resources and Environmental Studies, University of Kordofan, \\ Elobeid, Sudan
}

\begin{abstract}
The Senegalese grasshopper, Oedaleus senegalensis (Orthoptera: Acrididae) is known as pest of economic importance which cause damage to millet and sorghum crops besides pastures in western Sudan. The study was done to investigate the biology of the insect on its natural habitat. Observations in the field were made twice/ week, from April-November each year for three continuous seasons 2006/2007, 2007/2008 and 2008/2009, in two selected sites one around Gellabiya village in North Kordofan State west Elobeid town. The other was around Kuik village in South Kordofan State north Kadugli town. The nymphs and the adults were collected by sweep net from the field and transferred to the laboratory for study. Female adults of the Senegalese grasshopper were dissected and examined under binocular Microscope (Paralux, Optigue de précision CE 0602397) to investigate the fecundity through ovarioles numbers and function. Duration of each of the developmental stages of the pest was determined. Results showed that the mean number of ovarioles is 36 / ovary and two egg pods were laid /female. The mean fecundity was 44 eggs. The female laid eggs twice during life cycle. Ovariole function average was $76 \%$ in the first laying and $36 \%$ in the second laying. Mean developmental duration after hatching of $O$. senegalensis to adult (nymphal instars) was 25 day. The respective nymphal duration from the $1^{\text {st }}$ to the $5^{\text {th }}$ instar was 4, 5, 5, 5, and 6 days, respectively.
\end{abstract}

Keywords: Oedaleus senegalensis, Dissection, Ovariole, Fecundity, Kordofan.

\section{INTRODUCTION}

Among the relatively few indigenous species in the Sahel-Sahara zone (latitude 10 to $18^{\circ} \mathrm{N}$ ) the Senegalese grasshopper, Oedaleus senegalensis (Orthoptera: Acrididae) is economically considered as the most important pest species [1]. It is worth mentioning that during years 1975; 1976; 1978 and 1982 the Senegalese grasshopper inflected a serious damage to Pennisetumspp. 
(millet) and to pastures in Mali [2]. The pest also was reported in different countries of Africa and Asia as a pest of various food crops and pasture [3]. The Senegalese grasshopper $O$. senegalensis like all other locusts and grasshoppers passes through three stages: egg, nymph (hopper) and adult for the male and the female [4]. It has an incomplete metamorphosis. Eggs hatch into nymphs, primarily during the rainy seasons. Nymphs periodically shed their skins, usually five times as they grow. The successive growth stages are known as instars, after the last moult the immature adults have develop wings and able to fly. It has one or two generations produced in about two months in the rainy season, and sometimes they are three depends on the ecological factors and the food availability [5,6].Commonly, females lay eggs twice, rarely three times with five or six days between ovipositions and the maximum recorded number of eggs counted in the pod was 37 eggs and the minimum was 8 eggs [7]. Further, up to 45 eggs with an average of about 25 eggs per pod was counted Cheke [8], Launois-Luong [9]. studied egg production of $O$. senegalensis and assessed the ovarian state of females caught in the field and found the egg numbers per pod was 25 in average and number of pods laid per female was 1 or 2 depend on the different cultivations in the region of Maradi in Niger. Coop, et al. [10]. recorded that $O$. senegalensis fecundity reaches a maximum of 60 eggs per female and normally ranges from 25 eggs to 50 eggs, depending upon environmental conditions and densities above 20 females $/ \mathrm{m}^{2}$. Khalil [11] recorded incubation period of 12-15 days if the eggs were newly laid and it is 9-days when the eggs were from the preceding year.

Chiffaud and Mestre [12] mentioned that birth rate depends on fecundity of the females and fertility of the eggs. There are 40 ovarioles for O.senegalensis with 20 to 25 oocytes. Real figures recorded in the field by ovary dissection are 50 eggs per female. Chiffaud and Mestre [12] recorded range of 31 to 43 ovarioles/ female. After eggs hatching, the emerging insects find their way up the froth plug to the surface. They moult to the first instar. There are five nymphal stages, taking about three weeks to reach adult after eclosion, but short span as 15 days has been recorded $[8,13,14]$. Khalil [11] stated that the nymphal instars develop within 17-25 days in Sudan. The study is specifically being set to examine life history through dissection females and development of $O$. senegalensis under field conditions for better understanding of the pest biology

\section{MATERIALS AND METHODS}

\subsection{The Study Area}

The field work was conducted during cropping seasons 2006/07, 2007/08 and 2008/09; in two sites: one in North Kordofan State called Gellabiya, $\left(13^{\circ} 09^{\prime} \mathrm{N}: 30^{\circ} 07^{\prime} \mathrm{E}\right)$ about $12 \mathrm{~km}$ west of El-Obeid. The soil type in the site is sandy soil. The annual rainfall was about $556 \mathrm{~mm}, 573$ $\mathrm{mm}$ and $420 \mathrm{~mm}$ in seasons 2006/2007; 2007/2008 and 2008/2009, respectively. Dominant vegetations in this site consist of grass cover composed of annuals like: Cenchrusbiflorus (haskneet), Eragrostis tremula (Bano). Also there were some bushes and trees.

The other site in South Kordofan State at Kuik' (11 $\left.20^{\prime} \mathrm{N}: 29^{\circ} 42^{\prime} \mathrm{E}\right)$ about $35 \mathrm{~km}$ north of Kadugli. The soil type in this site is clay to loamy and silt soils. The hills are surrounding the site 
and there were some depressions in the area. Annual rainfall was $757 \mathrm{~mm} ; 889 \mathrm{~mm}$ and $598 \mathrm{~mm}$ in seasons 2006/2007, 2007/2008 and 2008/2009 from April to November, respectively. The vegetation around Kuik site falls in the category of savannah and consists basically of perennial grasses, like Dacctyoctenuim aegyptium (abuasabi), and Echinocloa colonum (difra). Also there were some different sorts of trees and bushes. The two sites are within the rain fed areas in the traditional agriculture sector of the Sudan, where milletand sorghum and sesame are cultivated. Extensive surveys were carried to study the biology of Oedaleus senegalensis (OSE) through its population dynamics in their natural habitats. Data were obtained by field visits; survey, and laboratory work was done.

\subsection{Field Work}

The adults with their brown and green colour, a distinct $\mathrm{x}$ mark and a crescent in the hind wings with posterior margin of pronotum broadly rounded were found and have been observed in the site wandering, feeding and reproducing. Field survey was done twice a week during the rainy season from April to November during the study period in the two sites. Some observations on copulation, oviposion, were taken in account in this study. Data obtained by survey were recorded in especial form. Sweep-net of $40 \mathrm{~cm}$ diameter and $60 \mathrm{~cm}$ hand stick was used to collect adults and nymphs. Collection was done by walking with normal paces through the vegetation swinging the net from side to side hundred times. The collected adults transferred to the laboratory. The collected $O$. senegalensis adults were kept alive for a short time and held in small bags or plastic jar with some holes when transferred from the field to the laboratory. The adult females were determined, separated then dissected. All grasshoppers' species nymphs in the site were swept by walking through the vegetation. A hundred strokes were used for each counting with a single stroke each five metre in different direction in the site then nymphs of $O S E$ with x mark on pronotum were determined, then separated, counted and duration of each stage was calculated.

\subsection{Laboratory Work}

Laboratory work was conducted in the laboratory of Plant Protection Department, Faculty of Natural Resources and Environmental Studies, University of Kordofan, Elobeid, Sudan. The life cycle studied with concentration on the nymphal and adults stages.

\subsection{Adult Female Dissection}

Fifteen females at least were dissected .Dissection of females was done in the same day of collection. The females of $O S E$ were killed by using killing jar then dissected by scalpels, scissors and clips (Pinces Dumont $n^{\circ} 5$ ). The purpose of this work was to study the statement of ovarioles maturation under stereomicroscope. Dissection of the females was done by cutting their wings; their legs and the head-using scissor. The ovary was examined by cutting along the side of the abdomen, where a thin line joining the upper and lower parts of the body (pleura membrane) then dorsal tergum was removed and after that ovaries which were pound together above the 
alimentary canal were inspected. Fats were removed using ringer solution which constitutes of water; sodium chloride; potassium chloride; calcium chloride and sodium bicarbonate.

\subsection{Number of Ovarioles}

The ovary of $O S E$ was examined after dissection with binocular and ovarioles were counted then assessed: Red bodies (resorption bodies), numbers of white bodies and ovarioles contain developing eggs $1 / 4,1 / 2,3 / 4$ and $4 / 4$ of its size; the number of eggs developing for the first time and the number in which one or more resorption has been happened or not.

\subsection{Fecundity}

In each study site eggs laid (fecundity) were assessed, and the numbers of eggs produced during the life of each female were counted; the minimum and maximum number of eggs were determined and recorded in dissection form.

\subsection{Development of the Nymphs}

The collected nymphs were sorted to green and brown. Also nymphs' stage was defined and their age was estimated. Average stage development time usually was estimated as the summation of each observed instar number, (adults are considered sixth instar for this purpose) divided by the number of individuals as mentioned by Berry, et al. [15]and the following formula was applied to calculate each the period of each stage

$$
\bar{X}=\frac{(H * N)+(A * 6)}{H+A}
$$

Where:

$\bar{X}=$ stage duration average

$\mathrm{H}=$ number of nymphs collected.

$\mathrm{N}=$ stage number $(1,2,3,4,5)$ for the five nymphal stages and 6 as constant considered of the adults.

$\mathrm{A}=$ number of adults collected

\section{RESULTS}

\subsection{Habitat of the Study Sites}

Results obtained from the field survey in the following two sites for three successive seasons 2006/2007, 2007/2008 and 2008/2009, showed that the habitat in the study area is suitable for the Senegalese grasshopper, Oedaleus senegalensis (Krauss).

\subsection{Copulation, Oviposition, Ovarioles Numbers and Fecundity}

Copulation was observed in opposite direction and/or the male was on top of the female. Oviposition by females has been observed and took about 1-2 hours in the mornings in bare and 
open ground of sandy soil at Gellabiya site and in silt soil at Kuik site or under scattered vegetations. In millet fields many holes were observed scattered and within 7-10 days hatching occurred after about one week of the first rains received and some eggs supposed to be from the preceding season.

\subsection{Female Ovarioles Number}

At Gellabiya site 1457 females were dissected and at Kuik site 738 females were dissected. The ovarian development was noticed according to the size of ovarioles. The mean number of ovarioles was $36 \pm 0.5$ in each ovary (Table 1).

\subsection{Fecundity of the Female}

Fecundity of 680 females was assessed at Gellabiya and Kuik sites. The females lay twice (2 pods) with an average of 44 eggs. In the first laying there were 27 eggs in the pod with $76 \%$ ovarioles functioning, while only $17 \mathrm{eggs}$ in the pod were counted in the second laying with $36 \%$ ovarioles functioning. The maximum eggs laid were about 54 and the minimum were 16 eggs (Table 2).

\subsection{Nymphs of Oedaleus Senegalensis Development}

Table 3 gives the average duration of the nymphs at Gellabiya and Kuik sites in the three seasons 2006/07, 2007/08 and 2008/09). The five nymphal instars N1, N2, N3, N4 and N5 duration was $4,5,5,5$, and 6 days, respectively, with total of 25 days to reach the adult stage. The five nymphal stages are in green and brown morphs.

\section{DISCUSSION}

Investigations pertinent to the pest biology are scanty or hardly available in Sudan in contrast to Sahelian countries of West Africa where some scientists like Colvin [16], Fisker, et al. [17].and Maiga, et al. [18] provided some data. Wherever, information are available it reflects heavy infestation with $O$. Senegalensis every year, which decreased millet crop production in the region. In Kordofan, knowledge regarding this serious pest has remained very much the same and received little attention. Therefore, the Senegalese grasshopper has been selected as a target pest to be discoursed in the present investigations.

Results obtained in the present study on the biology of $O$. senegalensis showed that the grasshopper nymph instars completely absent during the period extended from October to March during the study in seasons 2006/07, 2007/08 and 2008/09. Eggs hatch within one week or more after the area receive around $11 \mathrm{~mm}$ of rains in April 2007 at Kuik site. Colvin [16] in the Sahel recorded that the eggs of $O$. senegalensis may hatch two weeks after 8 to $15 \mathrm{~mm}$ of rain. Burt, et al. [19] mentioned only $8 \mathrm{~mm}$ were sufficient to cause eclosion nine days later. Therefore, these evidences leading to suggest that the eggs spent dry season in the ground and diapauses had been happened Gehrken and Doumbia [20] and emergence was triggered by the onset of the rains in 
April, May or June in the two sites. It is clear, in the present investigation the habitats of the study area are suitable for $O$. senegalensis breeding. Copulation was observed in opposite direction and/or on top in the beginning of the rainy season in both sites of the study area due to the arriving of the adults from outside or from the local breeding area.

In the current study, the reproduction has received much attention; particularly the state of ovarioles maturation development and their functioning through dissection of females. The results obtained showed that the female has mean number of 36 ovariole in the ovary (Table 1) but Luong-Skovmand [21] mentioned 40 ovariole for $O$. senegalensis with 20 to 25 oocytes. Further, in the field the average for most species is two egg pods per female in its lifetime. In the present study, the state of females ovariole assessed and the output showed that the female laid an average of $44 \pm 2$ eggs ( 2 egg pods) in lifetime. In the first laying there were $27 \pm 1 \mathrm{egg}$ with $76 \%$ ovariole functioning while only $17 \pm 3$ eggs were laid in the second time with $36 \%$ ovariole functioning as an average. The maximum eggs laid were $53 \pm 1 \mathrm{egg}$ and the minimum were $16 \pm 4$ eggs per female (Table 2). The variation in number of the eggs and the ovarioles functioning might be due to ecological conditions and it also depends very much on the physiological status. The results obtained about the reproduction supporting the findings of Launois-Luong [9], Pasture, et al. [22] , Cheke [8] and Luong-Skovmand [21]. In their studies and they mentioned more or less mean number of eggs in the range of our finding. On the other hand USAID [23] and Popov [2] recorded $O$. senegalensis fecundity may reaches a maximum of 60 eggs per female and normally ranges from 25 to 50 eggs.

In the present study, emergence was observed to start at Kuik site in the south of the region where rains begin relatively early in April and/or May. Only one generation was produced in this site. Unlike at Gellabiya site, which lying in the north of the region where the rains are somewhat later in June or early in July and emergence was started in July. Though, it appears that in general $O$. senegalensis produces two generations in the study area each year as the following scenario: the eggs hatching occurs with the onset of the rains in April, often, in May or June. Nymphs emerge after that and fledglings appear at the end of June or in early of July. Copulation takes place in July then eggs are laid and after incubation period, again eggs hatching resulted and the second generation is produced by mid-August onwards through September and October. Thus, duration of about two months for each generation has been expected, similar as that documented by Rowly and Bennett [6]. The five nymphal instars body length measures by calipar instrument are $7.5 \mathrm{~mm}, 9 \mathrm{~mm}, 11 \mathrm{~mm} 16 \mathrm{~mm}$ and $23 \mathrm{~mm}$ for the first, second, third, fourth and fifth instars, respectively .

In the current investigation the Senegalese grasshopper has five nymphal instars which become adults within about $25 \pm 1$ days of hatching (Table 3). Khalil [11] mentioned 17-25 day for nymphal instars development in the Sudan while Cheke [8] mentioned three weeks to reach adults in Nigeria. The variation may be due to the different environmental conditions. 


\section{CONCLUSION}

The Senegalese grasshopper has incomplete development and its fecundity is high and duration from egg emergence to adult is short and the adult become sexually mature within two weeks. The species produces two generations per year and enormous numbers may be produced which lead to outbreak. Therefore, in this study life history of the pest was understood which in turn help in sound management operation in the future in the region.

\section{ACKNOWLEDGEMENT}

Authors are very thankful to professor M.Lecoq and professor M.H.Lunong skovman of CIRAD , Monpellier,France for advice and guidelines.

\section{REFERENCES}

[1] P. J. C. Berges, J. Chiffaud, and J. Mestre, "Contribution of spatial remote to the identification of zones favourable to the Senegalese locust in the Sahel," Veille Climatique Satellitaire, vol. 40, pp. 2533, 1992 .

[2] G. B. Popov, "Sahelian grasshoppers," Overseas Developmen Natural Resources Institute Bulletin,London, vol. 87, 1988.

[3] A. Batten, "The Senegalese grasshopper oedaleus senegalensis Krauss," J. Appl. Ecol., vol. 6, pp. 27$45,1969$.

[4] D. R. Bhatia and P. J. S. Ahluwalia, "Oedaleus senegalensis Krauss (Orthoptera: Acrididae subfamily oedipodinae)," Plague in Rajasthan Plant Protection Bull., vol. 18, pp. 8-12, 1966.

[5] A. Steedman, Locust handbook, 3rd ed. vol. 240. NRI (Natural Resources Institute), Chatham. (1 ėre Ėd., 1966, COPR; 2éme Ėd., 1988, ODNRI), 1990.

[6] J. Rowly and O. Bennett, Grasshoppers \& locusts. The plague of the Sahel.Panos dossier. London.Paris. Washington: The Panos Institute, 1993.

[7] G. B. Popov, "Studies on oviposition, egg development and mortality in Oedaleus senegalensis (Krauss) (Orthoptera: Acrididae) in the Sahel," Centre for Overseas Pest Research, Miscellaneous Report. London 1980.

[8] R. A. Cheke, "A migrant pest of the Sahel: The Senegalese grasshopper,Oedaleus senegalensis," Phil. Trans. R. Soc. Lond, vol. B328, pp. 539-55, 1990.

[9] M. H. Launois-Luong, "Étude de la production des œufs d'Oedaleus senegalensis (Krauss) au Niger (Région de Maradi) (Original language French)," Bulletin de l'institut Fondamental d'Afrique Noire, (Série A), vol. 41, pp. 128-148, 1980.

[10] L. B. Coop, B. A. Croft, C. F. Murphy, and S. F. Miller, "Decision support system for economic analysis of grasshopper treatment operations in the African Sahel," Crop Protection, vol. 10, pp. 485$495,1991$.

[11] R. A. Khalil, Grasshoppers' species in the Sudan. Khartoum.Sudan: Training course on desert locust control in collaborated of plant protection directorate and AOAD, 1996. 
[12] J. Chiffaud and J. Mestre, "Reconnaisance des oothèques d'acridiens-apport des données anatomiqes de l'appareil reproducter," Sahel PVInfo., vol. 31, pp. 2-3, 1991.

[13] R. A. Cheke, L. C. D. Fishpool, and G. A. Forrest, "Oedaleus senegalensis (Krauss) (Orthoptera: Acrididae.Oedipodinae). An account of the 1977 outbreak in West Africa and notes on eclosion under laboratory conditions," Acrida, vol. 9, pp. 107-132, 1980 .

[14] L. D. C. Fishpool and R. A. Cheke, "Protracted eclosion and viability of Oedaleus senegalensis (Krauss) eggs (Orthoptera: Acrididae)," Entomologist's Monthly Magazine, vol. 119, pp. 215-219, 1983.

[15] J. S. Berry, J. A. Onsager, W. P. Kemp, T. McNary, L. John, D. Legg, J. A. Lockwood, and R. N. Foster, Assessing rangelands grasshopper populations, vol. 14. Their biology, identification and management.Handbook. Hand book: Grasshopper, 2001.

[16] J. Colvin, Biotic and a biotic factors affecting the population dynamics of the Senegalese Grasshopper, Oedaleus senegalensis. In new strategies in locust control. Switzerland: Birkhauser Verlag Basel, 1997.

[17] E. N. Fisker, J. Bak, and A. Niassy, "A simulation model to evaluate control strategies for grasshopper Oedaleus senegalensis in West Africa," Crop Protection, vol. 26, pp. 592-601, 2007.

[18] I. H. Maiga, J. A. Axelsen, K. Badji, and C. Kooyman, "Simulation studies of Senegalese grasshopper ecosystem interactions III: Optimization of grasshopper control," International Journal of Pest Management, vol. 55, pp. 113-120, 2009.

[19] P. J. A. Burt, J. Colvin, and S. M. Smith, "Remote sensing of rainfall by satellite as an aid to Oedaleus senegalensis (Orthoptera: Acrididae) control in the Sahel," Bulletin of Entomological Research, vol. 85, pp. 455-462, 1995.

[20] U. Gehrken and Y. O. Doumbia, "Diapause and quiescence in eggs of a tropical grasshopper Oedaleus senegalensis (Krauss)," J. Insect Physiol., vol. 42, pp. 483-491, 1996.

[21] M. H. Luong-Skovmand, Plan de cours Soudan. Montpellier ,France: Training Course on Grasshoppers Population Dynamic, 2005.

[22] P. Pasture, S. Smolikowski, and G. Thewys, Locusts and grasshoppers control: Deltamethrin file. Roussel Uclav- Division Agro. Paris, France, 1989.

[23] USAID, "Final report for locust, grasshopper control program in Chad, 1987 season," US Agency for International Development. N’Djamena 1987.

Table-1. Ovary condition and mean number of Oedaleus senegalensis females' ovarioles in samples collected from Gellabiya and Kuik sites in seasons 2006/07, 2007/08 and 2008/09

\begin{tabular}{lcccccc}
\hline & \multicolumn{3}{c}{$\begin{array}{c}\text { Gellabia } \\
\text { Site }\end{array}$} & \multicolumn{3}{c}{$\begin{array}{c}\text { Kuik } \\
\text { site }\end{array}$} \\
\hline $\begin{array}{l}\text { Ovary } \\
\text { Condition }\end{array}$ & $2006 / 07$ & $2007 / 08$ & $2008 / 09$ & $2006 / 07$ & $2007 / 08$ & $2008 / 09$ \\
\hline $\mathrm{PV}$ & $(111)$ & $(361)$ & $(69)$ & $(31)$ & $(162)$ & $(187)$ \\
& $36^{1}$ & $36^{1}$ & $37^{1}$ & $36^{1}$ & $35^{1}$ & $36^{1}$ \\
\hline $\mathrm{V}^{1 / 4}$ & $(29)$ & $(90)$ & $(23)$ & $(7)$ & $\mathrm{Nr}$ & $(02)$ \\
& $35^{1}$ & $35^{1}$ & $37^{1}$ & $35^{1}$ & & $36^{1}$ \\
\hline $\mathrm{V}_{1 / 2}$ & $(27)$ & $(60)$ & $(22)$ & $(17)$ & $\mathrm{Nr}$ & $(01)$ \\
& $36^{1}$ & $37^{1}$ & $36^{1}$ & $35^{1}$ & & $36^{1}$ \\
\hline
\end{tabular}




\begin{tabular}{lllcccl}
\hline $\mathrm{V}_{3 / 4}$ & $(33)$ & $(15)$ & $(19)$ & $(13)$ & $\mathrm{Nr}$ & $(01)$ \\
& $36^{1}$ & $38^{1}$ & $37^{1}$ & $35^{1}$ & & $36^{1}$ \\
\hline $\mathrm{V}_{4 / 4}$ & $(62)$ & $(121)$ & $(21)$ & $(16)$ & $(13)$ & $(02)$ \\
& $35^{1}$ & $37^{1}$ & $36^{1}$ & $36^{1}$ & $37^{1}$ & $35^{1}$ \\
\hline Lay & $(165)$ & $(139)$ & $(90)$ & $(113)$ & $(102)$ & $(71)$ \\
& $36^{1}$ & $36^{1}$ & $36^{1}$ & $36^{1}$ & $35^{1}$ & $35^{1}$ \\
\hline Total females & 427 & 786 & 244 & 197 & 277 & 264 \\
Dissected & & & & & & \\
\hline
\end{tabular}

Mean \pm std $=36 \pm 0.05$

$$
\begin{aligned}
& \text { ( ) Number of females dissected. } \\
& 1 \quad \text { Number of ovarioles in dissected female. } \\
& \mathrm{PV}=\text { Ovary on pre-vitellogensis. } \\
& \mathrm{V}_{1 / 4}=\text { Ovary on quarter vitellogensis stage. } \\
& \mathrm{V}_{1 / 2}=\text { Ovary on half vitellogensis stage. } \\
& \mathrm{V}_{3 / 4}=\text { Ovary on } 3 / 4 \text { vitellogensis stage. } \\
& \mathrm{V}_{4 / 4}=\text { Ovary on vitellogensis stage but not lay. } \\
& \mathrm{Lay}=\text { Female already lay the egg. (Spume). } \\
& \mathrm{Nr}=\text { not recorded. }
\end{aligned}
$$

Table-2. Fecundity of Oedaleus senegalensis females collected from Gellabiya and Kuik sites in seasons 2006/07, 2007/08 and 2008/09.

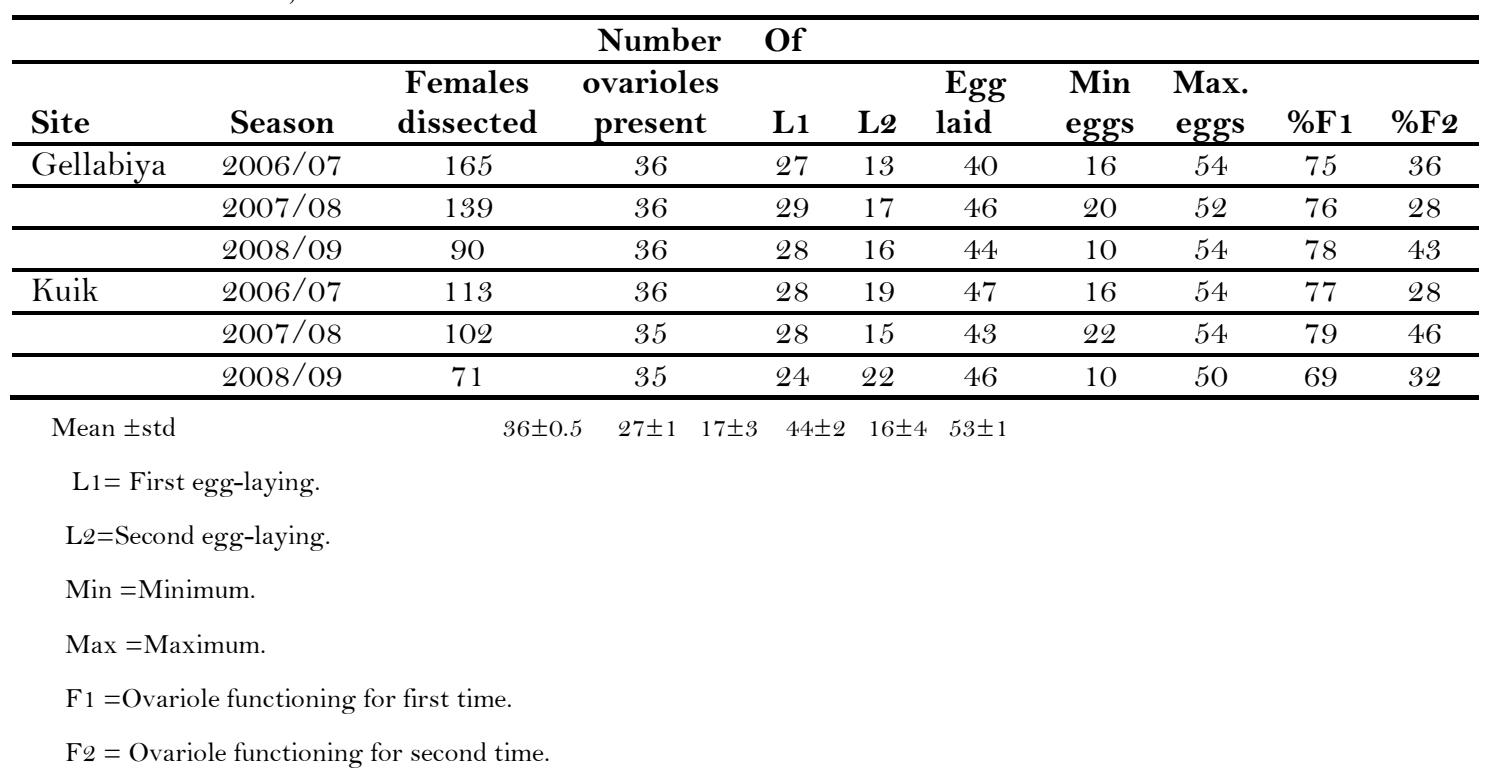


Table-3. Mean duration (days) of Oedaleus senegalensis nymphal instars atGellabiya and Kuik sites in natural vegetation during seasons 2006/07, 2007/08 and 2008/09.

\begin{tabular}{lcccccc}
\hline & \multicolumn{3}{l}{$\begin{array}{l}\text { Gellabiya } \\
\text { site }\end{array}$} & \multicolumn{3}{l}{$\begin{array}{l}\text { Kuik } \\
\text { site }\end{array}$} \\
\hline Stage & $2006 / 07$ & $2007 / 08$ & $2008 / 09$ & $2006 / 07$ & $2007 / 08$ & $2008 / 09$ \\
\hline$N 1$ & 4 & 4 & 3 & 4 & 4 & 4 \\
\hline$N 2$ & 4 & 5 & 5 & 4 & 5 & 5 \\
\hline$N 3$ & 5 & 6 & 5 & 6 & 5 & 5 \\
\hline$N 4$ & 5 & 6 & 6 & 5 & 5 & 5 \\
\hline$N 5$ & 6 & 6 & 6 & 5 & 5 & 6 \\
\hline Total & 24 & 27 & 25 & 24 & 24 & 25 \\
Days & & & & & &
\end{tabular}

Mean $\pm \mathrm{STD}=25 \pm 1$

$N 1=$ First instar, newly hatched nymph.

N2 =Second instar, wing pad downward nymph.

Ns $=$ Third instar, wing pad downward nymph.

N4 $=$ Fourth instar, wing pad upward nymph.

N5 $=$ Fifth instar (last stage). 